cause outstanding losses in many crops. Because there are few trained nematologists, many other important nematode problems on key food crops such as rice and paddy remain uninvestigated.

Because nematodes are soil organisms, control is especially difficult. Few satisfactory nematicides are known and these are too expensive for most agricultural crops in Europe. For these reasons, control is largely based on knowledge of host ranges, crop rotation, use of resistant varieties and eradication of weed hosts. Hotwater treatment of bulbs, stools or runners is also practised. These methods are valuable but are not always convenient or sufficiently effective. Chemical control at economic prices is the ultimate goal.

\title{
REFERENCES
}

Brown, E. B. (1957). Nematologica, 2, 369.

Christie, J. R. (1959). Plant Nematodes, Their Bionomics and Control. Gainsville, Florida: Agricultural Experiment Station, University of Florida.

Fenwick, D. W. (1957). Red ring disease of coconuts in Trinidad and Tobago. Colon. Rep. no. 406r7.

Filipjev, I. N. \& Schuurmans Stekhoven, J. B. (194I). A Manual of Agricultural Helminthology. Leiden: E. J. Brill.

Franklin, M. T. (I949). The Cyst-forming Species of Heterodera. Farnham Royal: Commonwealth Agricultural Bureaux.

Franklin, M. T. (1959). Nematologica, 4, 286.

Goodey, T. (1949). \%. Helminth. 21, 60.

Hague, N. G. M. (1959). Nematologica, 4, I Iо.

Harrison, B. D. \& Cadman, C. H. (1959). Nature, Lond., 184, 1624.

Hewitt, W. B., Raski, D. J. \& Goheen, A. C. (1958). Phytopathology, 48, 586.

Jha, A. \& Posnette, A. F. (1959). Nature, Lond., 184, 962.

Jones, F. G. W. (1957). Nematologica, 2, 257.

Jones, F. G. W. (1959). Tech. Bull. Minist. Agric., Lond., no. 7, p. 100.

Jones, F. G. W. (1959). In Plant Pathology, Problems and Progress 1908-1958, p. 395. [C. S. Holton, G. W. Fischer, R. W. Fulton, H. Hart and S. E. A. McCallan, editors.] Madison: University of Wisconsin Press.

Kalshoven, L. G. E. \& van der Vecht, T. J. (1950). Plagen van de Cultuurgezweissen in Indonesië, Vol. I. 's Gravenhage: van Hoeve.

Labruyère, R. E., den Ouden, H. \& Seinhorst, J. W. (1959). Nematologica, 4, 336.

Leach, R. (1959). Annu. Rep. Banana Board Res. Dep. Famaica 1957-8, p. 20.

Pitcher, R. W. \& Crosse, J. E. (1958). Nematologica, 3, 244.

Rolfe, S. W. H. (1959). Tech. Bull. Minist. Agric., Lond., no. 7, p. 95.

Seinhorst, J. W. (1956). Nematologica, I, 159.

Steiner, G. (1953). Bull. Fla Dep. Agric. no. I31.

Suit, R. F. \& Ducharme, E. P. (1957). Bull. Fla Pl. Bd, no. Ix.

Thompson, H. W. (1959). Tech. Bull. Minist. Agric., Lond., no. 7, p. 89.

Wallace, H. R. (1959). Ann. appl. Biol. 47, 350.

\section{Crop losses by insects and the problem of control}

\section{By M. J. WAY, Rothamsted Experimental Station, Harpenden, Herts}

'. . . animals which annually consume an amount of produce that sets calculation at defiance; and, indeed, if an approximation could be made to the quantity thus destroyed, the world would remain sceptical of the result obtained, considering it too marvellous to be received as truth.' (Curtis, I860.)

'Insecticides and other pesticides will be increasingly used, because agriculture cannot forego the benefits they confer, but this carries with it the obligation to know as much as possible about the ways in which they kill and their effects on animals other than those they are immediately directed against.' (Bawden, rg60.) 
In the late 1930's crop losses caused by insects in the U.S.A. were valued at about $\$ 734$ million annually or the equivalent of about I I $\frac{1}{2}$ million lost acres (Hyslop, I 938; Ordish, I952). More recent estimates rate the value of lost crops almost three times greater despite much increased use of insecticides (Anonymous, 1954). There are similar though less detailed estimates for other countries; for example, crop losses caused by insects in the British colonies were valued at over fioo million annually in the early 1950's (Symes, 1954; Hall, 1954) and in the United Kingdom the losses from all pests and diseases in 1947 were valued at about $f_{0} 78$ million (Ordish, 1952), of which perhaps a third to a half was caused by insects. These figures are mainly intelligent guesses and although inaccurate were considered to be underestimates. They bring home the magnitude of the losses implicit in the view that insects are man's greatest competitor for the earth's food resources; but, we need to know much more detail about the losses caused by each pest to determine if and when the losses it causes are important and whether control measures are justified. Admittedly, such measurement may not be necessary for some insects which cause obvious catastrophic losses, but most pests do not, and some may cause apparently serious damage from which the crop can largely recover (Jones, Dunning \& Humphries, r955).

Accurate pest assessments are made difficult by large variations in pest incidence in time and space even when conditions are as standardized as they can be with field crops. For example, at Rothamsted for the last 9 years, plots of the same variety of field bean have been drilled in mid-March at similar crop density on the same area of the Experimental Farm and, except perhaps in 1952, under similarly good conditions of soil fertility. Each year some plots were sprayed with an insecticide to control the bean aphid, Aphis fabae Scop., and others were left untreated.

Table I. Effects of infestations of bean aphid on crop yields of March-sown field beans at Rothamsted Farm

$\begin{array}{cc}\text { Peak no. of } \\ \text { Year } & \begin{array}{c}\text { aphids/plant } \\ \text { I952 }\end{array} \\ 1953 & 398 \\ 1954 & 34 \\ 1955 & 1260 \\ 1956 & 85 \\ 1957 & 0.2 \\ 1958 & 6920 \\ 1959 & 48\end{array}$

\begin{tabular}{cc}
\multicolumn{2}{c}{ Crop yield (cwt/acre) } \\
Insecticide- \\
treated
\end{tabular}

Crop loss from
aphid attack
(cwt/acre)
$13 \cdot 4$
$3 \cdot 5$
I $8 \cdot 7$
$2 \cdot 3$
I.8
I6.7
$4 \cdot 4$
I $8 \cdot 2$

Bean aphid numbers in the untreated plots (Table 1 ) varied enormously from a mean maximum of 0.2 per stem in 1956 to 6920 in 1957 but were not related in a simple way to losses, which varied from $\mathrm{x} .8 \mathrm{cwt} /$ acre in 1956 to 18.7 in 1954 . This was partly because yields of the aphid-free crop varied in relation to the weather, which also affects the ability of the infested plant to withstand a particular aphid population. Furthermore, if any of the above standardized conditions is changed, sowing date for example, aphid incidence and damage may be considerably altered. 
Table 2. Effect of sowing date on damage by bean aphid to spring-sown field beans at Rothamsted Farm

\begin{tabular}{|c|c|c|c|c|c|c|}
\hline \multirow[b]{3}{*}{$\begin{array}{l}\text { Date of } \\
\text { sowing }\end{array}$} & \multicolumn{3}{|c|}{ I955 } & \multicolumn{3}{|c|}{1957} \\
\hline & & Crop yiel & (cwt/acre) & & Crop yie & (cwt/acre) \\
\hline & $\begin{array}{l}\text { Peak no. of } \\
\text { aphids/plant }\end{array}$ & Untreated & $\begin{array}{l}\text { Insecticide- } \\
\text { treated }\end{array}$ & $\begin{array}{l}\text { Peak no, of } \\
\text { aphids/plant }\end{array}$ & Untreated & $\begin{array}{l}\text { Insecticide- } \\
\text { treated }\end{array}$ \\
\hline Mid-March & 85 & $16 \cdot 9$ & $19 \cdot 2$ & 6290 & 0 & $16 \cdot 7$ \\
\hline Early April & 480 & $13 \cdot 1$ & $18 \cdot 3$ & 一 & - & - \\
\hline Late April & $347^{\circ}$ & $6 \cdot 7$ & $12 \cdot 0$ & 575 & $9 \cdot 4$ & $15 \cdot 3$ \\
\hline Mid-May & 2820 & $2 \cdot 4$ & 10.5 & 38 & $12 \cdot 3$ & 13.8 \\
\hline
\end{tabular}

Table 2 shows that, in 1955 , when the bean-aphid infestation developed relatively late, it seriously damaged crops sown in late April and May, but not the mid-March sowing; conversely, in 1957 , a large early infestation destroyed the March-sown crop but did not develop on the later sowings.

These results suggest that accurate pest assessment is difficult, or perhaps impossible, and thus they explain why so few attempts have been made to determine crop losses by individual pests. Of the three outstanding examples all from Great Britain, two concern aphids.

Table 3. Calculated losses caused by yellows virus in Great Britain (modified from Hull, 1953, 1954, 1955, 1956, 1957, 1958, 1959)

\begin{tabular}{|c|c|c|}
\hline \multirow[b]{2}{*}{ Year } & \multicolumn{2}{|c|}{ Estimated loss of sugar yield } \\
\hline & tons $\times 10^{-3}$ & $\%$ \\
\hline 1946 & $19 \cdot 2$ & $2 \cdot 6$ \\
\hline I 947 & $22 \cdot 6$ & $4 \cdot 2$ \\
\hline 1948 & $55 \cdot 5$ & $7 \cdot 2$ \\
\hline I 949 & 151.0 & 19.6 \\
\hline I950 & $50 \cdot 7$ & $5 \cdot 6$ \\
\hline I95I & $14 \% 4$ & $1 \cdot 8$ \\
\hline 1952 & $77 \cdot 8$ & 10.0 \\
\hline 1953 & $25 \cdot 3$ & 2.9 \\
\hline 1954 & $31 \cdot 8$ & $4 \cdot 3$ \\
\hline 1955 & $24 \cdot 6$ & $4 \cdot 8$ \\
\hline 1956 & $12 \cdot 3$ & $\mathrm{I} \cdot 5$ \\
\hline r957 & $166 \cdot 2$ & 19.3 \\
\hline 1958 & $53 \cdot 8$ & $5 \cdot 8$ \\
\hline Mean & $54^{\circ} 2$ & $6 \cdot 9$ \\
\hline
\end{tabular}

\begin{tabular}{|c|}
\hline $\begin{array}{l}\text { Lost acreage } \\
\text { equivalent } \\
\left(\text { acres } \times 10^{-3}\right)\end{array}$ \\
\hline II \\
\hline I 5 \\
\hline $\begin{array}{l}29 \\
80\end{array}$ \\
\hline $\begin{array}{r}23 \\
8\end{array}$ \\
\hline 39 \\
\hline $\begin{array}{l}15 \\
18\end{array}$ \\
\hline 13 \\
\hline 6 \\
\hline 78 \\
\hline 24 \\
\hline 28 \\
\hline
\end{tabular}

Summarized results of the effects of aphid-transmitted virus yellows on sugar-beet (Table 3) (modified from Hull, 1953, 1954, 1955, 1956, 1957, 1958, 1959) show that yellows caused a mean annual loss of about 54000 tons of sugar from $1946-58$, which is about $7 \%$ of the total crop and equivalent to about 28000 lost acres out of the annual total of just over 400000 acres.

Strickland's (1957) detailed assessment of brussels sprouts losses caused by the cabbage aphid, Brevicoryne brassicae L., in the years I946-55 (Table 4) shows that, from an annual total of about 46000 acres, the equivalent of 7500 acres costing about $£ 860$ ooo would have been lost with no aphid control, but the loss might still 
have been about 4500 equivalent acres even if the standard control measures were applied when necessary. Including the cost of the control measures, the financial loss might still have been high-about $£ 700000$.

Table 4. Losses caused by cabbage aphids on brussels sprouts in England and Wales (from Strickland, 1957)

\begin{tabular}{|c|c|c|c|c|}
\hline & \multicolumn{2}{|c|}{$\begin{array}{l}\text { Acreage equivalents lost } \\
\quad\left(\text { acres } \times 10^{-3}\right)\end{array}$} & \multicolumn{2}{|c|}{$\begin{array}{l}\text { Financial statement } \\
\qquad\left(£ \times 10^{-3}\right)\end{array}$} \\
\hline Year & $\begin{array}{l}\text { Assuming } \\
\text { aphids not } \\
\text { controlled* }\end{array}$ & $\begin{array}{l}\text { Aphids } \\
\text { controlled in } \\
\text { late summer }\end{array}$ & $\begin{array}{l}\text { Loss if } \\
\text { aphids not } \\
\text { controlled* }\end{array}$ & $\begin{array}{l}\text { Gain from } \\
\text { late summer } \\
\text { control }\end{array}$ \\
\hline 1946 & $6.4 \pm 2.5$ & $3 \cdot 6$ & $853 \cdot 4 \pm 342 \cdot 3$ & I 64.4 \\
\hline I947 & $8 \cdot 7 \pm 2 \cdot 7$ & $4 \cdot 6$ & $980 \cdot 2 \pm 298 \cdot 5$ & $206 \cdot 6$ \\
\hline 1948 & $8 \cdot 5 \pm 2.9$ & $4 \cdot 7$ & $747^{\circ} 4 \pm 257^{\circ} \circ$ & $69: 4$ \\
\hline 1949 & $7 \cdot 9 \pm 2 \cdot 2$ & $4 \cdot 2$ & $739 \cdot x \pm 207 \cdot 7$ & I I I 6 \\
\hline 1950 & $6 \cdot 9 \pm 2 \cdot 4$ & $3 \cdot 8$ & $796 \cdot I \pm 279^{\circ} x$ & $130 \cdot 3$ \\
\hline $195 \mathrm{I}$ & $5 \cdot 7 \pm 2 \cdot 1$ & $3 \cdot 2$ & $811 \cdot 9 \pm 294 \cdot 2$ & 172.9 \\
\hline 1952 & $7 \cdot 7 \pm 2 \cdot 3$ & $4 \cdot 2$ & $1022 \cdot x \pm 313 \cdot I$ & $237 \cdot 1$ \\
\hline 1953 & $8 \cdot 4 \pm 2 \cdot 7$ & $4 \cdot 6$ & $703 \cdot 1 \pm 230^{\circ} 0$ & $62 \cdot 2$ \\
\hline 1954 & $5 \cdot 8 \pm 2 \cdot 3$ & $3 \cdot 3$ & $74^{8 \cdot 4} \pm 293 \cdot 2$ & $146 \cdot 5$ \\
\hline 1955 & $8 \cdot 2 \pm 2 \cdot 4$ & $4 \cdot 4$ & $1107.4 \pm 329^{\circ} 7$ & $26 \mathrm{I} \cdot 5$ \\
\hline Mean & $7 \cdot 5 \pm 2 \cdot 4$ & $4 \cdot 1$ & $868 \cdot 0 \pm 282 \cdot 2$ & $16 I \cdot 3$ \\
\hline
\end{tabular}

Such results imply that we should examine the efficiency of chemicals in preventing crop losses; it is appropriate to do so because this year may be considered to be the centenary of the modern era of pest control, initiated in 1860 by the use of arsenicals to control the Colorado potato-beetle. Moreover, it is now 20 years since the discovery of DDT which revolutionized pest control and has led to the development of many powerful synthetic organic insecticides, some so toxic that less than $\mathrm{I}$ oz of active ingredient per acre will control some pests.

Often the benefits of modern pest control measures are immediately obvious. For example, one spraying with a suitable systemic insecticide costing about 30 s./acre will prevent otherwise large crop losses by bean aphid (Way, Bardner, Van Baer \& Aitkenhead, I958). Minute amounts of $\gamma \mathrm{BHC}$ or dieldrin applied to the seed before drilling have solved the flea-beetle problem on brassica crops and greatly decreased wireworm losses in various crops. As a testimony to this, about 2 million acres of arable crops out of the total of 9 million in England and Wales received insecticidal seed dressings in $195^{8}$. Probably this was needed on only about half a million acres, but it is no doubt churlish to criticize such a cheap and simple means of insurance. Another outstanding example is the control of the aphids, which not only damage the sugar-beet crop directly but also indirectly by transmitting yellows virus. Chemical control measures developed by the Rothamsted Field Station at Dunholme were put into practice in Britain in 1957 , and in 1959 about 380000 out of the total of 408000 acres of sugar-beet were sprayed at least once. This not only increased root yield but also sugar content to give an increase of about $25 \%$ in total sugar yield (Hull, 1960). Even so, yellows was only partially controlled and it must also be remembered that 
in some years when aphids are less abundant the value of the increased yield would barely justify the cost of spraying. In the sugar-beet industry the unnecessary use of insecticides is prevented by an efficient advisory service, but with most other crops relatively little is known about the cost and efficiency of controls. Thus, in England and Wales, surveys of wireworm damage to commercial potato crops in $1955^{-6}$ (Baker \& Waines, 1957) showed that soil insecticides, applied to $16 \%$ of the fields, had only decreased damage by about half and, although the treatment was justified in a few fields with relatively large wireworm populations, on most fields the increased value of the crop scarcely paid for the cost of application let alone the cost of the chemical.

Relatively expensive control measures are without doubt justified where pests might otherwise cause local catastrophe; for example, very large sums are spent in controlling locusts and grasshoppers which were estimated to cause crop losses valued at more than $£ 30$ million annually (Uvarov, $195 \mathrm{I}$ ). Until recently it seems likely that the cost of the desert locust-control campaign in East Africa-about $f_{1} 1 \frac{1}{2}$ million annually, exceeded the value of the crop saved (Mudie, I955), though in North Africa some campaigns have had spectacular success-one in $195^{8-9}$ costing about 400 million francs saved losses valued at nearly 14000 million francs (Teisseire, I 960); also campaigns against the red and migratory locusts in Africa have apparently prevented both these species from breaking out and damaging crops for the last 5 years.

Where agriculture is underdeveloped, as in much of Africa, the yields of pest-free crops are often so small that the gains from pest control may scarcely justify the cost of the control measures. In contrast, there are some valuable temperate and subtropical fruit crops that can afford lavish expenditure on pest control. Consequently, many of them are now subjected to complicated routine spray programmes, comprising up to twenty separate sprays during the apple season in some parts of the U.S.A. (Chapman, 1955) and up to ten in Great Britain. There is reason to question the economics of this haphazard procedure for, although many pests have been controlled, a few may still do as much damage as formerly (Massee, 1956).

This, however, is perhaps the least serious problem, for such procedures have also enhanced the obvious defects of many present-day insecticides-their toxicity to man, to domestic and wild animals and their possible damage to the plant (the lead arsenate in the top soil of some orchards is said to be worth mining!). Furthermore, the frequent application of insecticides regardless of pest incidence has proved ideal for selecting out the few individuals of a species that happen to be resistant to the insecticides. They form the nucleus of subsequent resistant populations that are little affected by the insecticides that formerly controlled them (Way, 1959). The selection of resistant strains is favoured by the lack of specificity of most modern insecticides, many of which kill beneficial as well as harmful species. They may therefore interfere with natural control by insect parasites and predators, which are valuable because, unlike insecticides, they do not selectively favour the strains of the pest that resist the insecticide. This destruction of beneficial species has led to new pest problems in many parts of the world including Great Britain (Ripper, 
I956). For example, the fruit-tree red spider mite (not strictly an insect!) was once scarce in orchards but is now a serious pest because insecticides and fungicides applied to control other apple pests killed the natural enemies of the mite (Collyer, 1953). Suitable and very efficient chemicals were included in the spray programme to deal with this new pest, but now, in England and in many other parts of the world, populations of the red spider mite and of other mites are becoming resistant to the chemicals (Way, 1959).

Problems of this sort have also developed in controlling pests of arable crops especially in the U.S.A.; this has not yet happened in Britain, probably because our climate and traditional methods of agriculture make pests less important than in some other countries so that insecticides have been less used. In England and Wales the 20 million acres of grass and rough grazing are at present virtually untouched by insecticides. Out of the 9 million acres of arable land, 6 are cropped with cereals which so far have been seldom treated with insecticides other than seed dressings. The other important crops, potatoes, sugar-beet and brassicas, each of between 400000 and 600000 acres, are being increasingly treated. Thus over $26 \%$ of the 1959 potato crop had insecticide applied to the soil in which it was grown compared with $14 \%$ in 1955 ; the acreage of treated brussels sprouts increased from $22 \%$ in 1955 to $30 \%$ in 1957 to $74 \%$ in 1959 , and treated sugar-beet from $20 \%$ in 1957 to $95 \%$ in I 959 (Hull, I960). This trend, with its immediate benefits but potential problems, needs careful watching.

To sum up, the accurate assessment of crop losses by insects is difficult, if not impossible, but there is no doubt that if left uncontrolled many insect species can cause large losses. Great advances in insecticides have made it possible to prevent some of the losses; sometimes however, it is difficult to estimate whether the use of the available control measures is economically justified. Finally, much more work must be done before insecticides can be used to the best advantage and in such a way that their harmful effects are minimized.

I am grateful to the Ministry of Agriculture Plant Pathology Laboratory, Harpenden, for permission to quote unpublished data on acreages of insecticide-treated potatoes and brussels sprouts.

\section{REFERENCES}

Anonymous (1954). Losses in Agriculture. A Preliminary Appraisal for Review. U.S.D.A. Agricultural Research Service, Publ. A.R.S. 20-1.

Baker, C. B. M. \& Waines, R. A. (1957). Plant Path. 6, 115.

Bawden, F. C. (1960). Rep. Rothamst. exp. Sta. 1959, p. 23.

Chapman, P. J. (r955). F. econ. Ent. 48, $49 \mathrm{r}$.

Collyer, E. (1953). Chem. Eீ Ind. 40, ro44.

Curtis, J. (1860). Farm Insects. Glasgow: Blackie.

Hall, W. J. (1954). Colston Pap. 6, I.

Hull, R. (1953). Plant Path. 2, 39.

Hull, R. (1954). Plant Path. 3, 130.

Hull, R. (1955). Plant Path. 4, 134.

Hull, R. (1956). Plant Path. 5, 130.

Hull, R. (1957). Plant Path. 6, 131.

Hull, R. (1958). Plant Path. 7, 131. 
Hull, R. (I959). Plant Path. 8, I45.

Hull, R. (1960). Brit. Sug. Beet Rev. 28, I 3 .

Hyslop, J. A. (1938). Losses Occasioned by Insects, Mites and Ticks in the United States. U.S.D.A. Bureau of Entomology and Plant Quarantine. Publ. E444.

Jones, F. G. W., Dunning, R. A. \& Humphries, K. P. (1955). Ann. appl. Biol. 43, 63.

Massee, A. M. (1956). Proc. int. Congr. Ent. x. Montreal, 3, I63.

Mudie, F. (1955). Report of the Commission on the Desert Locust Control Organisation. Nairobi: East African High Commission.

Ordish, G. (1952). Untaken Harvest. London: Constable.

Ripper, W. E. (1956). Annu. Rev. Ent. 1, 403.

Strickland, A. H. (1957). Plant Path. 6, I.

Symes, C. B. (1954). Colston Pap. 6, i I.

Teisseire, M. (I 960$)$. La Lutte Antiacridienne dans les Départments Français d'Algérie et du Sahara au Cours de la Campagne r 958-9. Unpublished Report from Chef du Service de la Protection des Végétaux de l'Algérie.

Uvarov, B. P. (1951). Colon. Res. Publ. no. 10.

Way, M. J. (1959). N.A.A.S. Quart. Rev. no. 46 , p. 60.

Way, M. J., Bardner, R., Van Baer, R. \& Aitkenhead, P. (1958). Ann. appl. Biol. 46, 399.

\section{Losses resulting from the infestation of stored products by insects}

\section{By G. V. B. Herford, Pest Infestation Laboratory, Slough, Bucks}

My purpose in presenting this paper is not to provide a comprehensive survey of the extent and types of damage sustained by stored foodstuffs as a result of insect attack, nor to deal with the methods available for combating these losses. Both of these aspects have been covered by Parkin (1956).

In the short space available I would like to draw attention to the scale on which foodstuffs may be damaged by insects, the irrevocable nature of these losses, the problems attendant upon their assessment and, as far as possible, to indicate the progress that has been made towards their reduction. The problem of feeding the increasing world population is almost invariably considered in terms of increasing food production; very rarely is recognition given to the need for conserving our harvested crops for human as opposed to insect consumption. The few estimates that have been prepared on a global or continental scale indicate the short-sightedness of this attitude. FAO: Expert Committee (r946) published an estimate of $5 \%$ loss annually through insect infestation of all harvested cereals, peas, beans and oilseeds, equivalent to one-half of those products entering into world trade. This was officially considered to be a conservative estimate.

Insects, being cold-blooded organisms, will be more active and will cause most damage in tropical and subtropical countries, and where favourable climatic conditions are linked, as they often are, with a poorly organized pest-control system the consequences can be very serious indeed. Thus an on-the-spot study made by a Working Party of the United Nations (United Nations: Department of Economic Affairs, 1950) showed that the average losses sustained by six Latin American countries amounted to as much as $35 \%$ of cereals and pulses during storage each year. Even in temperate and more highly organized countries the insect damage to harvested crops is often very great; of the grain harvested in the Great Plains region of the United States, $10 \%$ is said to have been lost during one season's storage; and maize grown in the southern United States may lose up to $9 \%$ of its weight per 